\title{
The forbidden opinion polls of the Spanish Transition. Access to public information and Digital History
}

\author{
Raúl Magallón-Rosa \\ Departamento de Periodismo y Comunicación Audiovisual, Universidad Carlos III de Madrid, Calle Madrid, 126, 28903 Getafe, Madrid, \\ e-mail: raul.magallon@uc3m.es \\ ORCID iD: https://orcid.org/0000-0002-2236-7802
}

Submitted: 9 December 2017. Accepted: 23 June 2018

\begin{abstract}
The goal of this research is to analyse the role played by social media, the periodicals library and access to public information when revisiting collective memory on the Spanish Transition. The analysis is carried out based on an unpublished interview to Adolfo Suarez in 1995. During the interview, and off-the-record, former Spanish president Adolfo Suarez confessed to journalist Victoria Prego that the monarchy was not subjected to referendum because the opinion polls suggested they would lose. Those statements came to light 20 years later, after a special TV program broadcast by La Sexta Columna that turned Adolfo Suarez into a trending topic for several days.
\end{abstract}

Between 1955 and 1972 at least six opinion polls were carried out - perfectly documented and censored or silenced at the time - asking Spaniards about their preferences on the best government system for Spain.

KEYWORDS: Access to public information; Opinion polls; Transition; Monarchy; Republic.

Citation / Cómo citar este artículo: Magallón-Rosa, Raúl (2018) “The forbidden opinion polls of the Spanish Transition. Access to public information and Digital History." Data Modeling and Digital Approach for the Legal History of IberoAmerica". Culture \& History Digital Journal, 7 (2): e019. https://doi.org/10.3989/chdj.2018.19

RESUMEN: Las encuestas prohibidas de la transición española. El acceso a la información pública y la Historia Digital.- El objetivo de esta investigación es analizar el papel que ofrecen las redes sociales, la hemeroteca y el acceso a la información pública en la revisitación de la memoria colectiva de la transición española. El análisis se realiza a partir de una entrevista inédita de 1995 a Adolfo Suarez. Durante la entrevista, y off-the-record, el exPresidente del Gobierno Adolfo Suarez le confiesa a la periodista Victoria Prego que no sometieron a referéndum la monarquía porque las encuestas señalaban que perderían. Las declaraciones salieron a la luz 20 años después en un programa especial emitido en La Sexta Columna y convirtieron a Adolfo Suárez en trending topic durante varios días.

Entre 1955 y 1972 se realizaron al menos seis encuestas -perfectamente documentadas y censuradas o silenciadas en su momento- que preguntaban a los españoles por sus preferencias sobre el mejor sistema de Gobierno para España.

PALABRAS CLAVE: Acceso a la información pública; Encuestas; Transición; Monarquía; República.

Copyright: (C) 2018 CSIC. This is an open-access article distributed under the terms of the Creative Commons Attribution 4.0 International (CC BY 4.0) License.

\section{INTRODUCTION}

The goal of this research is to analyse the role played by social media, the periodicals library and journalistic memory when revisiting collective memory on the Span- ish Transition. This analysis came about from an unpublished interview to Adolfo Suarez by journalist Victoria Prego in 1995, which was broadcast 21 years later by TV program La Sexta Columna. After the broadcasting of statements that had remained unpublished for over 20 
years, journalists, historians and politicians tried to reformulate the consequences of this disclosure on the Transition Culture in the current scenario (Martínez, 2016). Victoria Prego herself, from her position as Chairwoman of the Press Association of Madrid, used her Twitter account as a platform to limit discourse and political horizons brought about by the statements published, 20 years after they were said.

Narrative after the broadcast of the interview urges us to discuss the role of access to public information when revisiting history (Cohen and Rosenzweig, 2005) as well as the framework of new technological media.

In this scenario, the role of historians is defined by the appearance of new material that can transform the predominant narrative on a specific fact: In this case, consensus on the monarchy as a stabilising institution during late Francoism (Payne, 2007) and the Spanish Transition (Pulpillo, 2016).

The four main hypotheses and explanations of the analysis presented here are:

- The hierarchical and structured reconstruction of history on the Spanish Transition is defined by new audio-visual materials that may come to light.

- Revisiting historical discourse on the Transition may show analogies with dialectic arguments regarding a Second Transition.

- The importance of declassifying official documents is highlighted again (including audio and video recordings).

- Social media may act as current conversation triggers on the past.

Some of the secondary goals of this analysis include being able to select other unpublished - or forgotten - information on the topic chosen that could serve as guidelines for new disclosures or research lines.

In order to carry out an analysis on the consequences and scope of the interview in the press, we have used the MyNews $^{1}$ tool and we have limited the time frame to one week $\left(18^{\text {th }}-25^{\text {th }}\right.$ of November 2016) after the broadcast of the unpublished interview. We have analysed a total of 287 news items or articles that appeared in the media during that period ${ }^{2}$.

\section{ADOLFO SUAREZ IS TRENDING TOPIC. SOCIAL MEDIA AS AN INSTIGATOR OF CONVERSATIONS ON THE PAST}

On the $18^{\text {th }}$ of November 2016, La Sexta Columna broadcast an unpublished interview to former Spanish president Adolfo Suarez by journalist Victoria Prego. The statements came to light in a special program, 21 years after the interview took place ${ }^{3}$. During the interview, and off the record, Adolfo Suarez, Spanish president from the $3^{\text {rd }}$ of July 1976 to the $25^{\text {th }}$ of February 1981, confessed to the journalist that the government did not subject the Monarchy to a referendum because the opinion polls suggested they would lose.
After becoming trending topic and generating, nearly simultaneously, numerous news items on the press, Victoria Prego, chairwoman of the Press Association of Madrid and joint director of daily El Independiente, signed an article entitled: "Una visita a la verdad del pasado [Visiting truths of the past]"4. The text read: "It was one of the many variables considered by Suarez as a hypothesis and it led him to carry out more than two opinion polls because he needed to know, even if just superficially, what this unknown country thought, a country that had not spoken for the last 37 years, a country he had to lead peacefully to democracy." Prego continued with the defence arguments by saying; "It must be said that, during the Spanish Transition, facts always happened steps ahead of Law, because otherwise the peaceful transition from a dictatorship to effective democracy, a process that in reality took 20 months, could not have taken place" 5 .

In turn, Casimiro García Abadillo, director of El Independiente, criticised on the $20^{\text {th }}$ of November all the controversy for two reasons ${ }^{6}$ : questioning the independence of journalists who published the information; and reopening the debate on the republic with the excuse that the people of Spain were deprived of voicing their opinion on the type of government after Franco's death.

At the same time, and due to the currency brought about by the interview's publication, Joan Garcés asserted in an interview to eldiario.es: "What Adolfo Suarez said is fully corroborated by facts. The fact that there were opinion polls before and after Franco's death is clear. Some of them are published and others were only to be accessed by those who commissioned them"7.

From this point of view, the first clue on the fact that those opinion polls were done during the last few years of Franco's regime was recovered by journalist Alejandro Torrús in daily Publico, with an article published on the $20^{\text {th }}$ of November 2016 entitled: "Un estudio de 1970 muestra que sólo el $20,8 \%$ de los españoles quería una monarquía 'después de Franco'" [A study from 1970 shows that only $20.8 \%$ of Spaniards wanted a monarchy after Franco's regime]". 8

The fact that there were 287 news items or articles on the press during that week was justified by a Twitter conversation feeding information on the past, constantly and increasingly.

\section{THE FORBIDDEN OPINION POLLS OF FRANCO'S REGIME. 1955-1972}

Between 1955 and 1972 at least six opinion polls were carried out - perfectly documented and censored or silenced at the time - asking Spaniards about their preferences on the best government system for Spain?

1. (1955) Led by professor José Luis Pinillos of the Universidad de Madrid in collaboration with CSIC. (Spanish National Research Council)

2. (1960) Report by Instituto de la Juventud (Spanish Institute for Youth). 
3. (1970) Foessa report (Fomento de Estudios Sociales y Sociología Aplicada) [Promotion of Social Studies and Applied Sociology].

4. (1971) Instituto de Opinión Pública [Public Opinion Institute], Study 1046.

5. (1971) Instituto de Opinión Pública, Study 1050.

6. (1972) Instituto de Opinión Pública, Study 1060.

Out of those six surveys, extracts from the first three had already been published and analysed individually (De Miguel 2000 and 2009; Carpintero, 2010). Nevertheless, until date no deep analysis had been done on the documents generated by the Instituto de Opinión Pública named Centro de Investigaciones Sociológicas (Centre of Sociology Research) or CIS, after 1977, when describing and explaining some of the decisions made in Spain during the Transition (Alcobendas, 2006).

Professor of psychology José Luis Pinillos carried out the first documented opinion poll on the preferences of Spaniards about the potential types of government in 1955. The survey, censored in Spain, was published by The New York Times in January 1956 and focused on university students in Madrid. Its publication had significant impact internationally. The New York Times' front page started with the following headline: "Students in Spain denounce regime" ${ }^{\prime \prime}$. The information was signed by Camille M. Cianfarra.

This opinion poll asked university students about their preferences on a government system for Spain. The possible answers were: liberal monarchy, authoritarian republic, liberal republic, military dictatorship, national syndicalism state and an authoritarian monarchy.

The results were collected by Heliodoro Carpintero, disciple of Jose Luis Pinillos, in an article published in 2010 entitled Psicología y Política en España: La Encuesta de Pinillos de 1955 [Psychology and politics in Spain: Pinillos'survey in 1955], in which it highlighted that "regarding political regimes, $60 \%$ responded that they were against totalitarian regimes, $20 \%$ accepted

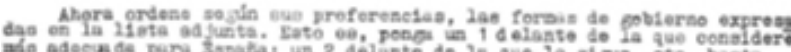

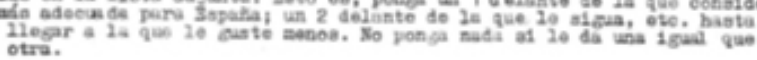

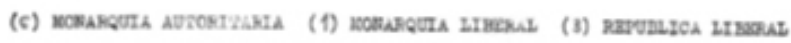

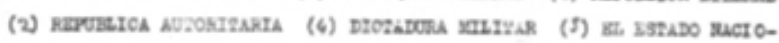
MAL-STMDOALISLA
}

Opinion poll carried out by Pinillos (1955).

Source: Heliodoro Carpintero (2010).



Source: Front page of The New York Times dated 4th of January 1956. 
them but did not accept the way public affairs were handled, and finally $20 \%$ were indifferent".

Based on the initial work by Pinillos, a complementary survey was done with 60 students of political science and law, with the following results:

- In favour of monarchy, 30\%

- In favour of a republic, $30 \%$

- Falangist, $10 \%$

- In favour of a military dictatorship, $10 \%$

- Indifferent, 20\%

As stated by Carpintero (2010), these original documents were accompanied by a note that read: "The original copy is for the Minister and a copy is kept for the author"11. Thus, Franco's regime received the first currency test, based on university students, about Spanish people's preferences on the best government system.

\section{The Foessa reports. The value of data to construct a political narrative}

The FOESSA Foundation (Promotion of Social Studies and Applied Sociology) was founded in 1965 with the support of Cáritas Española. In 1966, and coinciding with the approval of Ley 14/1966, de 18 de marzo, de Prensa e Imprenta [Law 14/1966 dated 18 ${ }^{\text {th }}$ of March on the Press and Printing] $]^{12}$ or "Fraga's law" (which abolished prior restraint), the report Informe sociológico sobre la situación social de España [Sociological report on the social situation in Spain] was presented.

In April 1969, FOESSA commissioned sociologist Amando de Miguel the second report, published in 1970 and entitled: Informe sociológico sobre la situación so- cial de España, 1970 [Sociologist report on the social situation in Spain, 1970], which aimed to respond to criticisms about the first report from 1966, which attempted to make a diagnosis of the Spanish social situation leaving aside political power.

As stated by De Miguel (2009) ${ }^{13}$, chapter 5 was censored at the last minute by express order of Luis Carrero Blanco, vice-president of the government at the time. Given that the book was already printed, the 5000 copies were purchased by Franco's government and distributed amongst the regime's high ranks.

At the time of republishing it, no one realised that although all pages of that chapter had been removed, the table of contents did include the reference as "Chapter 5 Political and associative life".

The fact that the title of the chapter appeared on the table of contents, although the text had been censored, made censorship even more visible and its footprint even more relevant. Amando de Miguel (2009) recalls, "Years later, part of that chapter was translated into English and was included in a volume compiled by Stanley Payne". In 2003, the whole chapter was published as an appendix of the book El final del franquismo. Testimonio personal [The end of Francoism. A personal testimony] by De Miguel himself.

Contrary to previous opinion polls that only asked indirectly about political issues, the 1970's analysis went a step further in order to gain insight into Spanish public opinion. Amongst other things, it asked whether it was possible to have a democracy without political parties. Something that was not acceptable:

- For 55\% of upper secondary school students.

- For $80 \%$ of university students.

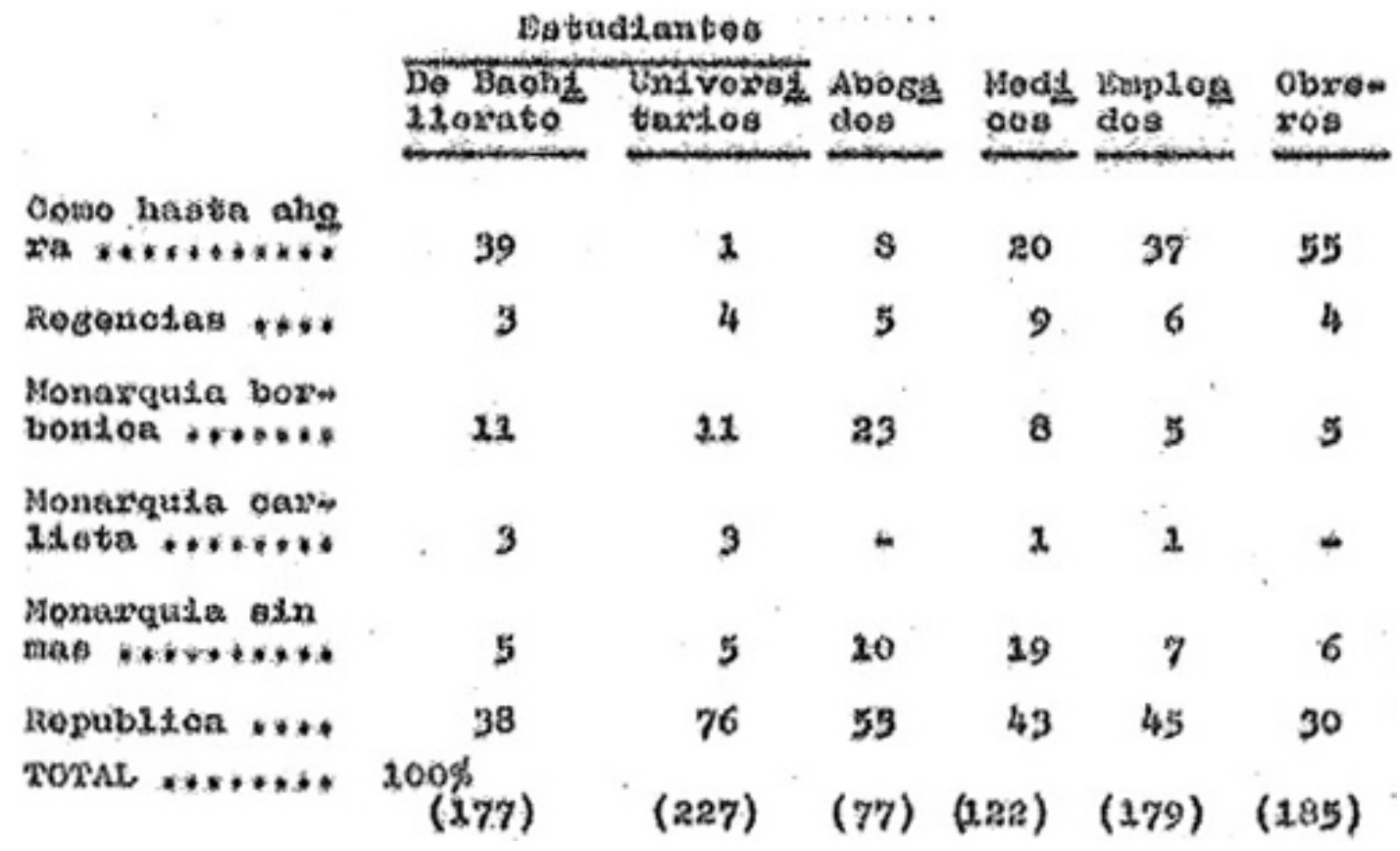

Source: Foessa, 1970. Chapter 5. 
- For $76 \%$ of lawyers.

- For $63 \%$ of doctors.

- For $61 \%$ of employees.

- For $57 \%$ of labourers.

This survey also highlights that a monarchy was not the first choice amongst any of the groups surveyed, contrary to a republic, which was the preferred option for university students, lawyers, doctors and employees.

\section{The historical value of documents unpublished by the CIS}

In July 1971, the Instituto de Opinión Pública carried out the study 1046, unpublished until now ${ }^{14}$, entitled "Cuestiones de actualidad política [Current politics issues]"15. The aim of this survey was to "know the diversity of opinions" on some current topics such as "the potential lack of political associations, some municipal problems, the government, national politics, the Prince of Spain, etcetera." The survey was addressed to a sample of 1000 people, over the age of 18 , of both genders, with residence in the municipalities of Madrid and Barcelona.

The first question of the questionnaire was: Could you tell us, approximately, if you remember when Prince Juan Carlos de Borbón was appointed as successor, as a king, of the head of state?

The answer: Do not know/Do not Answer reached $67 \%$, versus $33 \%$ who remembered the appointment date. It is important to point out that in 1969 Juan Carlos de Borbón was ratified as successor, as king, by the Fran- coist Cortes. $78 \%$ did not know how that appointment had been reached versus $22 \%$ who stated knowing.

When asked whether the appointment resolved the issue of Spanish political stability:

$-36 \%$ answered yes.

$-18 \%$ said only partly.

- $23 \%$ answered no.

- And 23\% did not have or did not give an opinion.

The numerous questions asked about the then Prince of Spain and the lack of public debate on the monarchy and the republic gives us an understanding of the complexity of the situation at the time, as well as enables us to gauge the importance of this survey when understanding the political strategy attempted in subsequent years.

In November 1971, the Instituto de Opinión Pública carried out another opinion poll entitled "Cuestiones de actualidad política [Current political issues]”. This study completed the work done four months before and had a direct question for the first time on the figure of the back then Prince Juan Carlos de Borbón. The short interval between both surveys is significant and symbolic, especially if we consider that the Instituto de Opinión Pública was founded in July 1963 and in the 8 years that elapsed it had never asked about the monarchy before. The study was based on 1000 interviews (641 in Madrid and 359 in Barcelona).

When asked what statement seemed more appropriate to them when talking about the "Monarchy"16, the answers were the following:

5. Voy a enseñarle ahora una serie de afirmaciones que la gente suele hacer cuando habla de la monarquía. ¿Quiere usted leerlas y decirme cuáles le parecen más acertadas?

(Mostrar tarjeta número 1.)

Asegura la transmisión del poder político

\begin{tabular}{|cc}
\hline Sí & No \\
\hline$(17)$ & \\
1 & 2 \\
\hline$(18)$ & \\
1 & 2 \\
\hline$(19)$ & \\
1 & 2 \\
\hline$(20)$ & \\
1 & 2 \\
\hline$(21)$ & \\
1 & 2 \\
\hline$(22)$ & \\
1 & 2 \\
\hline$(23)$ & \\
1 & 2 \\
\hline$(24)$ & \\
1 & 2 \\
\hline$(25)$ & \\
1 & 2 \\
\hline$(26)$ & \\
1 & 2 \\
\hline
\end{tabular}

Source: CIS/IOP (1971). 
Desearíamos comenzar esta entrevista con algunas preguntas sobre la persona del Príncipe de España, don Juan Carlos de Borbón.

1. ¿Podría indicarnos, aproximadamente, si lo recuerda, cuándo fue designado, el Príncipe don Juan Carlos de Borbón, como sucesor, a título de rey, del Jefe del Estado?

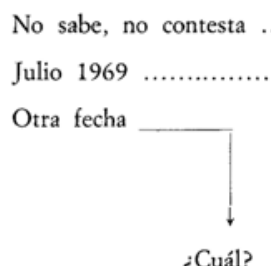

2. ¿Recuerda usted cómo se llegó a esta designación?

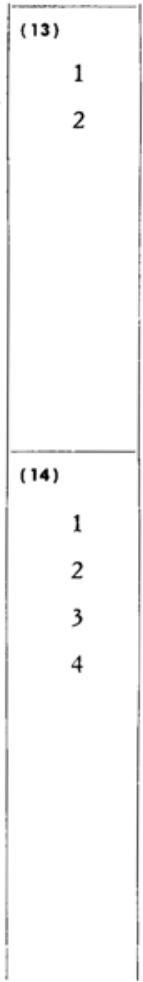

Source: Instituto de Opinión Pública. July 1971

\begin{tabular}{|c|c|c|c|}
\hline STATEMENTS ABOUT THE MONARCHY & JUL-71 & NOV-71 & DIFFERENCE \\
\hline It guarantees political power transfer & $42 \%$ & $29 \%$ & $-13 \%$ \\
\hline It prevents the most able from reaching power & $32 \%$ & $15 \%$ & $-17 \%$ \\
\hline It is God-given & $15 \%$ & $5 \%$ & $-10 \%$ \\
\hline It was overcome in the past & $36 \%$ & $15 \%$ & $-21 \%$ \\
\hline Guarantees order and stability & $40 \%$ & $25 \%$ & $-15 \%$ \\
\hline It is a government at the mercy of political parties & $19 \%$ & $5 \%$ & $-14 \%$ \\
\hline It is rooted in Spanish tradition and history & $54 \%$ & $30 \%$ & $-24 \%$ \\
\hline The people wish to elect their rulers & $59 \%$ & $34 \%$ & $-25 \%$ \\
\hline It is a balancing element of the interests of different social groups & $29 \%$ & $14 \%$ & $-15 \%$ \\
\hline It depends on what the King is like & $59 \%$ & $51 \%$ & $-8 \%$ \\
\hline
\end{tabular}

Source: Made personally with the data offered by the IOP.

The generation gap: A problem for the story of the Transition

Study 1060 carried out in December 1972 by the Instituto de Opinión Pública was entitled: "Encuesta sobre turismo interior y temas políticos" [Survey on domestic tourism and political issues]. The survey followed the interest of previous studies although questions were drafted differently.
When asked: "Do you wish your children to have a political system identical to the current one? $61 \%$ responded yes, versus $25 \%$ who responded No and $14 \%$ who responded Does not Know/Does not answer. In any case, it gives a glimpse of a clear generation gap, given that respondents aged 18 to 25 were equally divided in that answer, with $44 \%$ of the votes in both cases.

As for statement "The current Spanish regime is the best of all Spanish history", $47 \%$ stated they were in total 
agreement, $21 \%$ in little agreement, $10 \%$ slightly disagreed and $9 \%$ were in total disagreement.

On the other hand, when asked about how Franco's regime would fare in history, $51 \%$ responded it would be seen as a positive period and $39 \%$ as "a period with good things and bad things." However, the answers changed depending on the age group. Of respondents aged 18 to $25,51 \%$ responded as a "period with good things and bad things" and only $37 \%$ responded "as a positive period".

\section{THE MEDIA NARRATIVE OF THE MONARCHY. FROM LATE FRANCOISM TO THE TRANSITION}

The three studies of the Instituto de Opinión Pública carried out between 1971 and 1972 that asked about issues related to monarchy have in common a growing interest on the role of the media when configuring the symbolic image of the then Prince Juan Carlos. Surveys asked whether the respondents followed the activities of the back then Prince Juan Carlos on the radio, magazines, press and television. Given the possible inclusion of Prince Juan Carlos into "Spanish households", the answer was:

- $57 \%$ responded that they would not like to see more frequently references to the activities and life of the Prince on TV.

- However, 68\% found Prince Juan Carlos "friendly" and only $9 \%$ stated that they did not find him friendly.
In Study 1050 from 1971 about the Prince's activities, the answers varied depending on the media questioned about: $32 \%$ answered they knew about him mostly from $\mathrm{TV}, 17 \%$ answered via newspapers (four months earlier the figure was $9 \%$ ), and only $11 \%$ followed the Prince's activities via the radio (58\% never followed his activities via the radio).

Including questions on Prince Juan Carlos on the surveys carried out by the Instituto de Opinión Pública showed the leaders' growing interest to know what Spaniards thought about a potential succession. Nevertheless, the monograph on the monarchy and Prince Juan Carlos dating from November 1971, with 31 questions on the topic, showed clearly that a media strategy was being planned given the approaching transition.

As for the historical context, we must remember that this period coincided with the beginning of studies on the socalled setting agenda by McCombs and Shaw (1972). Their work aimed to show that the "media may not be successful much of the time in telling people what to think, but it is stunningly successful in telling its readers what to think about" (Cohen, 1963). Thus, opinion polls allowed them to create communication strategies necessary to invite the future king of Spain to enter Spanish households via their television sets.

\section{CHALLENGES FOR THE HIERARCHICAL AND STRUCTURED RECONSTRUCTION OF HISTORY}

The way to define historiographical work was not only affected by the storing and management of informa-

63. Le voy a leer varias frases respecto de cada una de las cuales le ruego que me diga si está:

Totalmente de acuerdo, un poco de acuerdo, un poco de desacuerdo, totalmente en desacuer-

do. (Entrevistador mostrar cartón A)

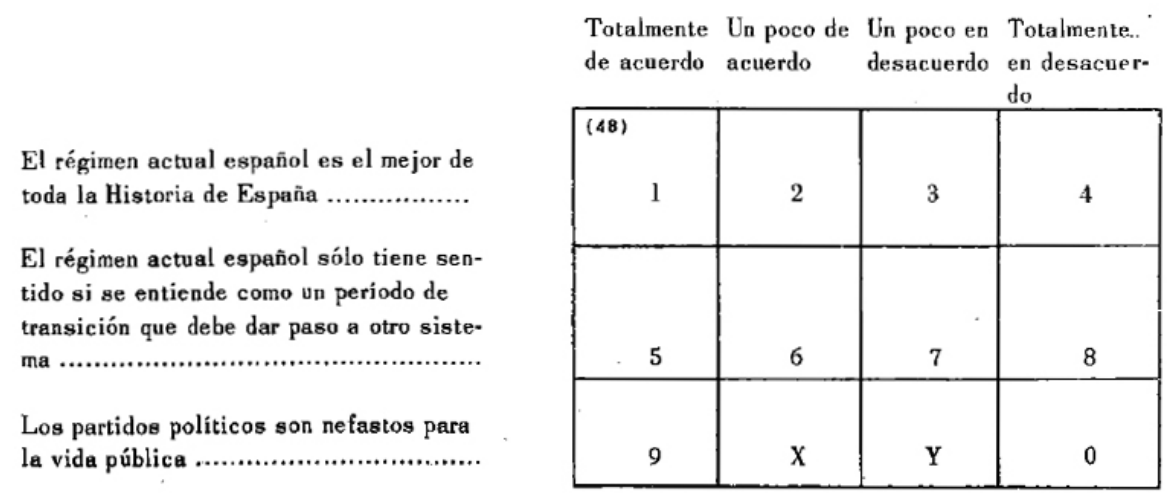

Source: IOP (1972).

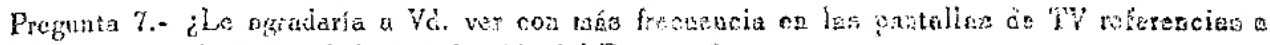
las actividades y $a$ la vida del Prílsijs?

$\frac{S 1}{c} \quad \frac{N n}{y} \quad$ Sinspinión

TOT:Lit)

31

57

12

Source: Instituto de Opinión Pública. Study 1046 (1971). 
tion, but also by the writing, research and classification processes, by collaborative learning and by new narratives that aim to convey new shared experiences (Magallón, 2017).

Nevertheless, as stated by Wright Mills (1959), "historians represent the organised memory of mankind and that memory, as written history, is enormously malleable".

\section{The abolition of the Law on Official Secrets of 1968}

On the $28^{\text {th }}$ of November 2016, Parliament unanimously approved to take into consideration a Bill to reform the law on official secrets of 1968, a Bill promoted by the PNV (Basque Nationalist Party). The law in force does not have time restrictions nor does it have an independent body to declassify state secrets.

The reform proposal for Law 9/1968 on official secrets $^{17}$, dated $5^{\text {th }}$ of April. had 169 votes in favour, 3 votes against and 162 abstentions. In March 2018, nearly 18 months later, Parliament's presidential board unblocked the proposal ${ }^{18}$.

The text presented included "the obligation when classifying material to establish an enforcement period, which cannot exceed 25 years for matters classified as secret and 10 years for those classified as reserved, except if the Council of Ministers stipulates an exceptional and reasoned deferment, solely for secret matters, for a new period of a maximum of 10 years." 19

Moreover, changes were made to the ante penultimate paragraph on presenting the reasons that stated that "from the point of view of legal certainty and citizens' guarantees, it is important to highlight that the Law stipulates the need to notify information media when something is declared as "classified information" when it is expected that the media may come to know about it, as well as recording the classification of the matter so that individuals have the obligation to collaborate as per article 9.1".

\section{The importance of the periodicals library and access to public information for the development of History}

As stated by Galline and Noiret, "the internet and the digital media do not question the object of historical work, but impact the way of thinking about the past and the way of communicating about that past. They do it at least in three ways: showing the intrinsically communicative nature of history, affecting the ways and timing of historic research and blurring and redesigning the figures of authors and readers" (2011:17). In this new scenario in which digital humanities work, the culture of open data tries to obtain added value from information, but contrary to what happened until present, this information not only generates its own value by being reserved to a few, rather by being available to be interpreted and translated by any company, institution, social group or individual who is interested in working with it (Magallón, 2017).

In this regard, it is necessary to reflect on the role that present time historians will have when working with the growing amount of information managed by public authorities, institutions, and local, regional and national governments.

The periodicals library and access to public information (Meseguer, 2016) become a common axis from which to work on the declassification of historical documentation.

From an architectural standpoint, the need to think about the prior design of a digital archive structure that enables its mutation and enlargement to other documentary sources, such as social media, is clear, given that the latter can play an important role in the recovery of censored history when revisiting the Transition, or when disseminating knowledge that has been silenced by official discourse.

\section{CONCLUSIONS. OPEN DIGITAL SOURCES WHEN REVISITING HISTORY}

Between 1955 and 1972 six surveys were perfectly documented showing that Spaniards' preferences on the government system that should replace Franco's dictatorship did not have to coincide with the interests of the leaders at the time. What the different opinion polls show us is that not even a 30-year dictatorship had managed to reach the necessary social and cultural consensus to bring together social and legal legitimation.

The censored opinion poll of the Fomento de Estudios de Sociología Aplicada Foundation (FOESSA) of 1970 confirmed that the monarchy was not the preferred option amongst Spaniards. We must recall that in 1969 Juan Carlos de Borbón was ratified as successor, as king, by the Francoist Cortes. Changes in Spaniards' opinions on the monarchy and on Prince Juan Carlos, in so little time, beyond methodological issues, are clarifying and significant.

Clarifying because it seems demonstrated that the media were organising and executing their social function of consensus very effectively, and thus the future king of Spain became part of Spanish households as one more member of the family. Significant, because of the level of detail on the different media and the monarchy offered by the survey. In this regard, we must highlight that Study 1060 from December 1972 showed that, amongst those aged 18 to $25,51 \%$ responded that Franco's political regime would be considered as a "period with good things and bad things" and only $37 \%$ answered as a "positive period".

In any case, it seems clear that, beyond those results, opinion polls allowed for the creation of communication strategies that were necessary so that in a brief period of time the word republic disappeared from Spaniards' imagination $^{20}$

In turn, and compared to traditional, closed and controlled documents by a few (both when drafting those documents and when distributing them), the internet brings to contemporary thinking the open access idea, which entails that it is no longer only a few players who can publish information (and thus become a source) and 
that no longer will only a few voices distribute it (and thus decide who will be the future sources).

The issue of open data and access to public information must be analysed from two viewpoints: First, from that of past events that become current again due to the appearance of new documentation that broadens the perspective on a past event. Secondly, from the present, with those news that, from the moment they have happened, change the development of future history.

From this point of view, the prior design of a digital architecture of historical documented facts fosters two complementary scenarios through interoperability mechanisms: on the one hand, revisiting historical discourse that aims to establish analogies for the dialectic reasoning on the past, and secondly, bringing back the importance of declassifying official documents (including audio and video recordings) as part of historians' documentary process.

In this line, Bresciano (2015) stresses, "one of the greatest challenges is to identify, conceptualise, classify and describe properly the new types of sources, that have constitutive and relational features that are very varied. We must also bear in mind that growing differences of different types of documents will continue to intensify and that it is necessary to anticipate to changes." In this regard, Fickers (2012), stated that "from the beginning, historical work was characterised by a double ambition: first, to find and collect historical sources as traces of past times (the historian as archivist and chronicler), second, to produce a coherent narrative of that past by interpreting the sources based on contemporary questions and interests (the historian as interpreter)."

This dialogue becomes a challenge when deciding how a historical event will be remembered in the future, but also an opportunity to understand that social media can play an important role in the recovery of censored history.

\section{ACKNOWLEDGEMENTS}

This research is part of the research project HISMEDI financed by the Ministry of Economy and Competitiveness and by the European Regional Development Fund (ERDF) with reference HAR-2015-63582-P MINECO/ FEDER Director: Matilde Eiroa https://uc3m.libguides.com/hismedi

\section{NOTES}

$1 \mathrm{http}: / /$ hemeroteca.mynews.es/

2 We must point out that news groups such as Vocento share their opinion pieces amongst their regional dailies.

3 The interview can be watched in the following link: http:// www.lasexta.com/programas/sexta-columna/noticias/asi-confeso-adolfo-suarez-por-que-no-hubo-referendum-monarquia-orepublica-haciamos-encuestas-y-perdiamos_20161118582ef9fe 0cf244336f09709f.html

$4 \mathrm{http} / /$ www.elindependiente.com/opinion/2016/11/19/una-visita-a-la-verdad-del-pasado/

5 http://www.elindependiente.com/opinion/2016/11/19/una-visita-a-la-verdad-del-pasado
6 http://www.elindependiente.com/opinion/2016/11/20/los-falsos-debates-sobre-la-libertad-y-la-republica/

7 http://www.eldiario.es/sociedad/ilegitimo-monarquia-debatelegitimidad-Garces 0 582692490.html

8 http://www.publico.e-es/politica/estudio-1970-muestra-20-espanoles.html

9 https://www.bez.es/355153603/Las-encuestas-prohibidasMonarquia-o-Republica.html

$10 \mathrm{https} / / /$ mobile.nytimes.com/1956/01/04/archives/students-inspain-denounce-regime-totalitarian-rule-of-franco.html

11 http://psicologia.ucm.es/data/cont/docs/29-2013-04-25-art6.pdf

12 https://www.boe.es/buscar/act.php?id=BOE-A-1966-3501

$13 \mathrm{http}: / /$ revistas.ucm.es/index.php/POSO/article/view/ POSO0909230091A

14 The three unpublished studies of the CIS can be requested through its database. Please refer to: http://www.cis.es/cis/ opencms/ES/NoticiasNovedades/InfoCIS/2014/PlataformaOnLineBancodeDatos.html

15 The first chairman of the Instituto de Opinión Pública in 1963 was Luis González Seara, who later cofounded Cambio 16 and Diario 16 and was Minister of Universities and Research in Adolfo Suarez's cabinet.

16 From a methodological aspect it is important to note that in the first questionnaire the options were not limited, whereas in the second they had to choose from 3 options.

17 Law 9/1968, dated $5^{\text {th }}$ of April, on official secrets. Available in: https:/www.boe.es/buscar/doc.php?id=BOE-A-1968-444 [consulted on 30/June/2018]

18 Amongst other reasons because the Popular Party and the Socialist Party had asked for 12 subsequent postponements in order to present amendments https://politica.elpais.com/politica/2017/05/01/actualidad/1493648069_349780.html

19 http://www.congreso.es/public oficiales/L12/CONG/BOCG/B/ BOCG-12-B-32-1.PDF

20 We must recall that republican parties were not allowed to participate in the first national election.

\section{REFERENCES}

Alcobendas, Ma Pilar (2006) IOP. Historia del Instituto de la Opinión Pública.1963-1977. Centro de Investigaciones Sociológicas. Madrid.

Bresciano, J.A. (2015) "Fuentes históricas para un nuevo tiempo. Los procesos de globalización y su abordaje heurístico”. https:// www.academia.edu/2699807/Fuentes_hist\%C3\%B3ricas_para un nuevo tiempo. Los procesos de globalizaci $\% \mathrm{C} 3 \% \mathrm{~B} 3 \mathrm{n}$ su abordaje heur\%C3\%ADstico [accessed 23/july/2018]

Carpintero, H. (2010) "Psicología y Política en España: La Encuesta de Pinillos de 1955". Psychologia Latina. 2010, Vol. 1 No. 2: 88-96. http://psicologia.ucm.es/data/cont/docs/29-2013-04-25art6.pdf [accessed 23/july/2018]

Cianfarra, C. (1956) "Students in Spain denounce regime". The New York Times, Jan. $4^{\text {th }} \cdot$ p.1. https://mobile.nytimes.com/1956/01/04/ archives/students-in-spain-denounce-regime-totalitarian-rule-offranco.html [accessed 23/july/2018]

Cohen, Daniel \& Rosenzweig, Roy (2005): "Digital history. A guide to gathering, preserving, and presenting the past on the web". Center for History and New Media. http://chnm.gmu.edu/digital history/ [accessed 23/july/2018]

Cohen, B. (1963) The Press and Foreign Policy, Princeton University Press.

De Miguel, A. (2000) Dos generaciones de jóvenes 1960-1998. Edición Injuve. Madrid.

De Miguel, A. (2003) El final del franquismo. Testimonio personal. Marcial Pons Historia, Madrid.

De Miguel, A. (2009) "Historia personal de una desmesura: los "foessas". Política y Sociedad, 2009, Vol. 46 Núm. 3: 91-102. http://revistas.ucm.es/index.php/POSO/article/view/ POSO0909230091A/21769 [accessed 23/july/2018]

Fickers, A. (2012) "Towards a New Digital Historicism? Doing History In The Age Of Abundance". In Journal of European Television 
History and Culture, 1, 1, p. 19-26. http://ojs.viewjournal.eu/index. $\mathrm{php} / \mathrm{view} /$ article/viewFile/jethc004/4 [accessed 23/july/2018]

Foessa (1970) II Informe Foessa. Informe sociológico sobre la situación social de España. Coord. Amando de Miguel. Fomento de Estudios Sociales y Sociología Aplicada. Madrid.

Instituto Opinión Pública (1971a) "Cuestiones de actualidad. Estudio 1046”. Centro de Investigaciones Sociológicas. Madrid.

Instituto Opinión Pública (1971b) "Cuestiones de actualidad. Estudio 1050". Centro de Investigaciones Sociológicas. Madrid. Instituto Opinión Pública (1972) "Encuesta sobre turismo interior y temas políticos". Estudio 1060. Centro de Investigaciones Sociológicas. Madrid.

Magallón, R. (2017) "Datos abiertos y acceso a la información pública en la reconstrucción de la historia digital", en Historia y comunicación social 22.2, 297-308. https://revistas.ucm.es/ index.php/HICS/article/view/57845 [accessed 23/july/2018]

Magallón-Rosa, R. (2018) "La biblioteca digital sobre Donald Trump. Fact-checking frente a fake news", en Estudios sobre el Mensaje Periodístico 24 (1), 273-282. http://revistas.ucm.es/ index.php/ESMP/article/view/59949 [accessed 23/july/2018]

Martínez, Guillem (coord.) (2016) CT o la cultura de la transición. Debolsillo, Madrid.
Mccombs, M. E. y Shaw, D. L. (1972) "The Agenda-Setting Function of Mass Media”. The Public Opinion Quarterly, 36(2): 176-187.

Melo, J.A. (2011) "Historia digital: la memoria en el archivo infinito". En: Historia Crítica 43: 82-103. http://historiacritica.uniandes. edu.co/view.php/694/index.php?id=694 [accessed 23/july/2018]

Mesa, R. (ed.) (2006) Jaraneros y alborotadores. Universidad Complutense, Madrid.

Meseguer, J. M. (2016) "El acceso a la información pública y los requerimientos de identificación". Revista española de la transparencia, (3), 65-68. https://drive.google.com/file/d/ 0BzZV66dM4HCTeVhGOVBfM1preUU/view [accessed 23/ july/2018]

Payne, S. G. (2007) “¿Tardofranquismo o pretransición?” Documentos de Trabajo. Cuadernos de la España Contemporánea, (2), 1. http://personal.us.es/clanga/uploads/payne tardofranquismo.pdf [accessed 23/july/2018]

Pulpillo, C. (2016) "Bibliografía actualizada de la transición española". En La transición a la democracia: estudios, testimonios y reflexiones (Coord. Stanley Payne) 285-309. CSED: Universidad Rey Juan Carlos. Madrid.

Wright Mills, C. (1959). La imaginación sociológica. Madrid: Fondo de cultura económica de España. 